\title{
Penerapan Metode Snowball Throwing untuk Meningkatkan Motivasi dan Hasil Belajar Siswa pada Pembelajaran Agama Hindu
}

\author{
Dewa Gde Brata Tapa ${ }^{1^{*}}$
}

${ }^{1}$ SD Negeri 6 Gianyar, Bali, Indonesia

\section{A R T I C L E I N F O}

Article history:

Received 10 October 2020

Received in revised form

30 November 2020

Accepted 10 January 2021

Available online 01

February 2021

\section{Kata Kunci:}

Metode Snowball

Throwing, Motivasi

Belajar, Hasil Belajar

Keywords:

Snowball Throwing

Method, Learning

Motivation, Learning

Outcomes

\begin{abstract}
A B S T R A K
Tujuan penulisan penelitian tindakan kelas ini adalah untuk meningkatkan motivasi dan hasil belajar Agama Hindu siswa kelas VI di SD melalui penerapan metode Snowball Throwing. Metode pengumpulan datanya adalah observasi dan tes hasil belajar. Metode analisis datanya adalah deskriptif. Dengan hasil yang diperoleh dari penelitian ini adalah model pembelajaran yang diterapkan dapat meningkatkan hasil belajar siswa. Ini terbukti dari hasil yang diperoleh pada awalnya hanya mencapai rata-rata 7,06 dan ketuntasan belajar $66,00 \%$, pada siklus I meningkat menjadi 7,80 dengan ketuntasan belajar $87 \%$ dan pada Siklus II meningkat menjadi 8,87 dengan ketuntasan belajar mencapai $100 \%$. Kesimpulan yang diperoleh dari penelitian ini adalah penerapan metode Snowball Throwing dapat meningkatkan motivasi dan hasil belajar Agama Hindu siswa kelas VI SD Negeri 6 Gianyar tahun pelajaran 2018/2019.
\end{abstract}

\section{A B S T R A K}

The purpose of writing this classroom action research is to increase motivation and learning outcomes of Hindu students in grade VI at SD through the application of the Snowball Throwing method. The data collection methods are observation and learning result test. The data analysis method is descriptive. With the results obtained from this study, the applied learning model can improve student learning outcomes. This is evident from the results obtained at first only reaching an average of 7.06 and learning completeness $66.00 \%$, in cycle I it increased to 7.80 with $87 \%$ completeness of learning and in Cycle II it increased to 8.87 with completeness of learning achieving $100 \%$. The conclusion obtained from this research is that the application of the Snowball Throwing method can increase motivation and learning outcomes of Hinduism for grade VI students of SD Negeri 6 Gianyar in the 2018/2019 academic year.

\section{Pendahuluan}

Pembelajaran adalah segala aktifitas yang melibatkan interaksi antara siswa dengan sumber belajar. Pembelajaran bertujuan tidak hanya memahami dan menguasai apa dan bagaimana itu terjadi, tetapi juga memberi pemahaman dan penguasaan (F. Fitriani et al., 2013) Pembelajaran yang baik adalah pembelajaran yang memberikan kesempatan siswa untuk belajar membangun dan menggali pengetahunnya sendiri. Pembelajaran yang mampu melibatakan aktivitas siswa tentunya tidak mudah dibutuhkan sebuah rencana yang matang dan penuh persiapan. Pembelajaran yang demikian tentunya memerlukan model pembelajaran. Model pembelajaran yang digunakan adalah model pembelajaran Inovatif, kreatif, efektif dan menyenangkan yang mendorong siswa untuk termotivasi (Nafisah, 2014). Model pembelajaran yang menekankan pada keaktifan siswa di dalam proses pembelajaran (Dinarto, 2019). Namun kenyataanya masih banyak proses pembelajaran yang dilakukan masih menggunkan model pembelajaran yang berpusat pada guru, sehingga mempengaruhi motivasi siswa dalam proses 
pembelajaran. Hal ini sesuai dengan kenyataa yang ditemukan disekolah tempat penelitian dilakukan. Dimana guru agama Hindu di SD Negeri 6 Gianyar masih menggunakan / menerapkan model pembelajaran yang konvensional (tradisional), yaitu tipe mengajar guru yang masih monotun / pembelajaran masih bersifat satu arah, guru agama Hindu masih mendominasi kelas dengan metode ceramahnya sehingga berpengaruh pada pembelajaran yang pasif, banyak siswa yang mengantuk, ada yang lain-lain sibuk ngobrol dengan temannya sehingga interaksi hanya berlangsung satu arah yaitu hanya dari guru ke pada siswa. Dimana siswa diperlakukan hanya sebagai obyek yang menerima materi pelajaran agama Hindu dengan mendengarkan dan mencatat begitu saja. Kurangnya penggunaan metode yang kooperatif / yang inovatif, kurangnya penggunaan media pembelajaran serta kurangnya pemberian kesempatan pada anak didik untuk mencoba, melakukan menemukan sendiri sehingga apa yang dipelajari siswa dalam pelajaran agama Hindu cendrung masih bersifat abstrak, pembelajaran seperti itu hanya mencekoki siswa sebatas menghafal sehingga berdampak pada rendahnya perolehan nilai siswa pada materi yadnya. Oleh karena terjadinya ketimpangan antara harapan dan kenyataannya (das sain dan Das sollen) di SD Negeri 6 Gianyar yaitu model mengajar guru agama Hindu yang masih monoton dengan metode konvensional yang berdampak terhadap motivasi siswa dalam proses belajar. Kegiatan pembelajaran pun menjadi pasif dan membosankan. Interaksi antara guru dan peserta didik yang kaku menyebabkan peserta didi t idak termotivasi untuk belajar (Oktiani, 2017).

Motivasi belajar adalah kekuatan pendorong baik dari dalam maupun luar diri siswa untuk belajar dalam rangka mengadakan perubahan tingkah laku untuk mencapai tujuan yang ingin dicapai dengan didukung beberapa indikator seperti: hasrat dan keinginan, kebutuhan dalam belajar, harapan dan cita-cita masa depan, penghargaan dalam belajar, kegiatan yang menarik, serta lingkungan belajar yang kondusif (Fauziah et al., 2017; Putri Ningrat et al., 2018). Motivasi dapat mendorong siswa ingin melakukan kegiatan belajar. Tanpa adanya motivasi siswa tidak akan bersemangat mengikuti proses belajar mengajar apalagi belajar mandiri di rumah, motivasi bukan saja penting karena faktor penyebab belajar, namun juga memperlancar belajar dan prestasi belajar (Mulyasih \& Suryani, 2016; Sudikno \& Aminah, 2014). Semakin tinggi motivasi yang dimiliki siswa akan mendorong siswa belajar lebih giat lagi dan frekuensi belajarnya menjadi semakin meningkat, sehingga hasil belajarnya pun meningkat (Amirullah \& Hardianti, 2016; Rachmah et al., 2019). Bedasarkan jabaran tersebut motivasi sangat berperan penting dalam proses pembelajaran adanya motivasi tentunya akan mempengaruhi hasil belajar. Oleh sebab itulah untuk membuat siswa termotivasi untuk belajar tentunya menggunkan model pembelajaran yang inovatif. Salah satu model inovatif yang bisa digunkan adalah metode Snowball Throwing.

Snowball throwing dapat meningkatkan aktifitas siswa (Gustomo \& Sudarman, 2015). Snowball throwing dapat membangkitkan keberanian murid dalam mengemukakan pertanyaan kepada teman yang lain maupun guru (Fitriani et al., 2019). Snowball Throwing adalah kegiatan pembelajaran yang disertai dengan permainan pelemparan kertas berisi pertanyaan yang dibentuk menyerupai bola salju, sehingga kegiatan belajar mengajar menjadi jauh lebih menyenangkan (Gusti, 2019; Sartono, 2017). Snowball throwing siswa dituntut untuk dapat menguasai materi, melatih siswa berfikir kreatif dan belajar bertanggung jawab dalam menjalankan tugas (Yuliati, 2015). Snowball Throwing dapat menigkatkan aktivitas dan kreatifitas siswa, melatih siswa belajar mandiri dalam pengetahuan berdasarkan diskusi, mengembangkan kemampuan (Januwardana et al., 2014; Rosidah, 2017). Metode snowball throwing menstimulus siswa untuk menyelesaikan masalah, komunikasi, penalaran, dan kepercayaan diri (Kurniawan, 2017). Metode pembelajaran snowball throwing peserta didik menjadi ter- motivasi untuk belajar kreatif, dan berkat kegigihan guru dalam merancang atau mengelola pembelajaran snowball throwing menjadikan prestasi anak (Makhfud \& Imron, 2020). Jabaran tentang model snowball throwing memberikan suasana pembelajaran yang lebih menarik dimana siswa aktif belajar sambil bermain dengan pertanyaan yang dikemas semenarik mungkin. Tentunya hal ini akan memberikan pengaruh poasitif terhadap minat siswa dalam proses pembelajaran. Kelebihan model pembelajaran ini menjadi salah satu alasan mengapa penelitian ini dilakukan dan merumuskan tujuan penelitian mengkaji penerapan metode Snowball Throwing untuk meningkatkan motivasi dan hasil belajar siswa pada pembelajaran agama hindu di kelas VI SD Negeri 6 Gianyar Tahun Pelajaran 2016/2017".

\section{Metode}

Penelitian ini dilaksanakan di SD Negeri 6 Gianyar yang terletak di Lingkungan Candi Baru Desa Gianyar, Kecamatan Gianyar, Kabupaten Gianyar, Sekolah ini dapat dijangkau dengan kendaraan roda dua, roda empat, maupun dengan berjalan kaki. Dengan letaknya yang strategis, sekolah ini tentu mempunyai prosfek yang baik pada masa-masa yang akan datang karena sekolah ini merupakan sekolah imbas namun walaupun demikian sekolah ini sekolah yang terpaporit di kota Gianyar karena prestasinya, baik di tingkat 
kabupaten maupun di tingkat propinsi. Penelitian ini merupakan Penelitian Tindakan Kelas (PTK) dengan model penelitian Kunandar (2010), dan Penelitian ini dilaksanakan pada materi yadnya dengan satu standar kompetensi dan dilakukan dengan dua siklus penelitian. Siklus pertama dan kedua hanya untuk mengetahui penerapan metode Snowball Throwing dan Implikasinya dapat meningkatkan motivasi dan hasil belajar siswa. Adapun presedur Penelitian Tindakan Kelas pada Siklus I dan Siklus seterusnya kalau dipandang perlu tergantung dari hasil siklus I, dilaksanakan melalui empat tahapan yaitu perencanaan penelitian dilaksanakan bersama teman guru Agama Hindu sejawat. kegiatan yang dilakukan pada bagian ini adalah: 1) Merencanakan Pembelajaran dengan menggunakan metode Snowball Throwing, 2) Menyusun Rencana Penelitian (RP), 3) Menyusun tes tulis dan 4) Menyusun tehnik pengumpulan data. Pelaksanaan tindakan yang berupa kegiatan pembelajaran di kelas dilaksanakan oleh guru. Kegiatan yang dilaksanakan adalah memberikan pretes untuk mengetahui pengetahuan awal siswa dan melaksanakan proses pembelajaran dengan menggunakan metode Snowball Throwing. Observasi dan evaluasi dilakukan oleh guru pada siswa setelah kegiatan inti pembelajaran. Adapun kegiatan yang dilakukan pada kegiatan ini adalah: memberikan tes tulis untuk mengukur kemampuan / daya serap siswa. dan mencatat hal-hal penting yang terjadi dalam pembelajaran seperti kelemahan-kelemahan dan kelebihan-kelebihan dalam pembelajaran. Repleksi dilakukan oleh guru dan teman guru sejawat. Refleksi dilakukan pada setiap pembelajaran dan akhir siklus. Kegiatan yang dilakukan pada tahapan ini adalah mengkaji dan menganalisis segala temuan pada tindakan tes tulis, hasil observasi , hasil pengamatan terhadap hal-hal penting yang terjadi selama proses pembelajaran. Hasil refleksi siklus pertama digunakan dasar perbaikan dan penyempurnaan perencanaan dan pelaksanaan tindakan pada siklus ke dua. Data dalam penelitian ini tergolong data primer yang diperoleh secara langsung dari siswa. Dengan demikian yang menjadi sumber data dalam penelitian ini adalah siswa kelas VI SD Negeri 6 Gianyar Tahun pelajaran 2016/2017 dan guru / teman sejawat. Data dalam penelitian ini berupa data kualitatif dan kuantitatif. Data kualitatif diperoleh melalui observasi dan wawancara, sedangkan data kuantitatif berufa hasil belajar siswa (Nilai) di peroleh melalui tes tulis.

\section{Hasil dan Pembahasan}

Penerapan Strategi Pembelajaran Agama Hindu dengan menggunakan metode Snowball Throwing adalah metode pembelajaran yang dilakukan dengan tiga kegiatan yaitu 1) Kegiatan awal 2) kegiatan Inti yang terdiri dari fase eksplorasi, elaborasi, serta fase kompirmasi, dan 3) Kegiatan Akhir. Dalam kegiatan inti siswa di bimbing membentuk kelompok diskusi, kemudian siswa berdiskusi membuat butir-butir pertanyaan, lembar pertanyaan tersebut kemudian dibentuk bulatan seperti bola salju. Selama 3 menit semua kelompok saling lempar bola salju pertanyaan, kemudian masing-masing kelompok mempresentasikan / menjawab butir-butir pertanyaan yang menjadi bagiannya dengan main poin-poinan (model cerdas cermat). Berdasarkan evaluasi hasil belajar Agama Hindu yang telah dilakukan, didapatkan hasil yang menunjukan perolehan nilai rata rata kelas hasil belajar Agama Hindu siswa masih sangat rendah, yaitu dengan perolehan skor nilai secara klasikal yaitu 304 dan rata-rata kelas 7,05, dimana siswa yang mencapai persentase ketuntasan belajar $66 \%$, dan yang tidak mencapai ketuntasan adalah $34 \%$, dengan tuntutan KKM untuk mata pelajaran Agama Hindu kelas VI SD Negeri 6 Gianyar adalah 7,5. Berdasarkan penerapan metode pembelajaran Snowball Throwing pada siklus I, didapatkan hasil bahwa rata rata hasil belajar Agama Hindu siswa sebesar 7,8 dari jumlah nilai 337 seluruh siswa di kelas VI SD Negeri 6 Gianyar, dan prosentase ketuntasan belajarnya adalah 87\%, yang tidak tuntas adalah $13 \%$. Hasil ini belum maksimal, karena belum mecapai indikator keberhasilan penelitian yang mencanangkan dengan minimal prosentase ketuntasan belajar mencapai $100 \%$. Dikarenakan hasil belum maksimal pada siklus I, maka siklus dilanjutkan pada siklus II dengan tindakan yang sangat maksimal dan pelaksanaan yang betul-betul mengikuti kebenaran teori sesuai dengan metode Snowball Throwing dalam pembelajaran Agama Hindu di kelas VI SD Negeri 6 Gianyar, dimana hasil yang diperoleh pada siklus II ini ternyata hasil belajar Agama Hindu meningkat secara signifikan dengan nilai rata-rata 8,87 dengan jumlah nilai klaksikal mencapai 381,5, dan ketuntasan belajarnya adalah $100 \%$.

Penerapan Strategi Pembelajaran agama Hindu dengan menggunakan metode Snowball Throwing yaitu pada siklus I dapat meningkatkan perolehan nilai siswa dari 7,05 menjadi 7,8 namun walaupun demikian ternyata masih ada siswa yang belum tuntas sebanyak 6 orang/13\% belum tuntas, dengan kata lain ketuntasan kelasikal hanya $=87 \%$. Dengan demikian penerapan metode tersebut belum maksimal sesuai dengan target untuk meningkatkan ketuntasan belajar siswa sampai $100 \%$ hal terebut terjadi karena belum maksimalnya guru mengelola diskusi kelompok sehingga ada sebagian siswa yang belum berperan aktif mereka hanya mengandalkan ketua, wakil dan sekretaris kelompok yang bekerja, kurangnya motivasi belajar siswa, oleh karena itu tindakan dilanjutkan pada siklus II. Pada siklus II lebih diintensipkan kerja kelompok siswa semua siswa diberdayakan, sehingga semua siswa menjadi aktif dan 
termotifasi untuk belajar yang berdampak pada meningkatnya perolehan nilai siswa dari rata-rata kelas 7,8 menjadi 8,87 dan ketuntasan belajar menjadi 100\%. Dengan demikian karena sudah sesuai dengan target tindakan, maka PTK ini dihentikan sampai disini

Untuk mengatasi permasalahan di atas, diterapkan metode pembelajaran Snowball Throwing. Metode pembelajaran Snowball Throwing adalah suatu model pembelajaran yang diawali dengan pembentuka kelompok yang diwakili ketua kelompok untuk mendapat tugas dari guru kemudian masingmasing siswa membuat pertanyaan yang dibentuk seperti bola (kertas pertanyaan) lalu dilempar ke siswa lain yang masing-masing siswa menjawab pertanyaan dari bola yang diperoleh" (Mufid, 2017). Metode pembelajaran Snowball Throwing dapat menigkatkan aktivitas dan kreatifitas siswa, melatih siswa belajar mandiri dalam pengetahuan berdasarkan diskusi, mengembangkan kemampuan berpikir siswa dalam mendiskusikan dan meyelesaikan tugas belajar, mengembangkan kemampuan mengemukakan pendapat, meningkatkan kemampuan menjelaskan kembali materi yang diperoleh berdasarkan diskusi, dan meningkatkan hasil belajar siswa. Tentunya ini berdampak terhadap motivasi belajar siswa.

Motivasi belajar adalah kekuatan pendorong baik dari dalam maupun luar diri siswa untuk belajar dalam rangka mengadakan perubahan tingkah laku untuk mencapai tujuan yang ingin dicapai dengan didukung beberapa indikator seperti: hasrat dan keinginan, kebutuhan dalam belajar, harapan dan cita-cita masa depan, penghargaan dalam belajar, kegiatan yang menarik, serta lingkungan belajar yang kondusif (Fauziah et al., 2017; Putri Ningrat et al., 2018). Motivasi dapat mendorong siswa ingin melakukan kegiatan belajar. Tanpa adanya motivasi siswa tidak akan bersemangat mengikuti proses belajar mengajar apalagi belajar mandiri di rumah, motivasi bukan saja penting karena faktor penyebab belajar, namun juga memperlancar belajar dan prestasi belajar (Mulyasih \& Suryani, 2016; Sudikno \& Aminah, 2014). Semakin tinggi motivasi yang dimiliki siswa akan mendorong siswa belajar lebih giat lagi dan frekuensi belajarnya menjadi semakin meningkat, sehingga hasil belajarnya pun meningkat (Amirullah \& Hardianti, 2016; Rachmah et al., 2019). Bedasarkan jabaran tersebut motivasi sangat berperan penting dalam proses pembelajaran adanya motivasi tentunya akan mempengaruhi hasil belajar. Oleh sebab itulah untuk membuat siswa termotivasi untuk belajar tentunya menggunkan model pembelajaran yang inovatif. Salah satu model inovatif yang bisa digunkan adalah metode Snowball Throwing.

Snowball throwing dapat meningkatkan aktifitas siswa (Gustomo \& Sudarman, 2015). Snowball throwing dapat membangkitkan keberanian murid dalam mengemukakan pertanyaan kepada teman yang lain maupun guru (Fitriani et al., 2019). Snowball Throwing adalah kegiatan pembelajaran yang disertai dengan permainan pelemparan kertas berisi pertanyaan yang dibentuk menyerupai bola salju, sehingga kegiatan belajar mengajar menjadi jauh lebih menyenangkan (Gusti, 2019; Sartono, 2017). Snowball throwing siswa dituntut untuk dapat menguasai materi, melatih siswa berfikir kreatif dan belajar bertanggung jawab dalam menjalankan tugas (Yuliati, 2015). Snowball Throwing dapat menigkatkan aktivitas dan kreatifitas siswa, melatih siswa belajar mandiri dalam pengetahuan berdasarkan diskusi, mengembangkan kemampuan (Januwardana et al., 2014; Rosidah, 2017). Metode snowball throwing menstimulus siswa untuk menyelesaikan masalah, komunikasi, penalaran, dan kepercayaan diri (Kurniawan, 2017). Metode pembelajaran snowball throwing peserta didik menjadi termotivasi untuk belajar kreatif, dan berkat kegigihan guru dalam merancang atau mengelola pembelajaran snowball throwing menjadi kan prestasi anak (Makhfud \& Imron, 2020). Jabaran tentang model snowball throwing memberikan suasana pembelajaran yang lebih menarik dimana siswa aktif belajar sambil bermain dengan pertanyaan yang dikemas semenarik mungkin.

Hasil penelitian ini sejalan dengan hasil penelitian yang dilakukan oleh Rosidah, (2017) menunjukkan bahwa penerapan model pembelajaran tipe Snowball Throwing dapat meningkatkan hasil belajar siswa. Selanjutnya penelitian yang dilakukan oleh Agustina \& Akmal, (2015) dengan Hasil penelitian menunjukkan melalui metode Snowball Throwing berbantuan media konkret dapat meningkatkan keaktifan dan hasil belajar IPA siswa Sekolah Dasar. Hal ini dapat dilihat dari skor awal keaktifan belajar pada siklus I sebesar 3,625 (90,62\%) meningkat di siklus II menjadi 3,81 (95,25\%). Hasil belajar siswa secara kognitif meningkat dari siklus I pencapaian ketuntasan secara klasikal rata-rata kelas mencapai 65,22\% dengan rata-rata kelas 70,86 meningkat di siklus II menjadi 91,30\% dengan ratarata kelas sebesar 79,33. Bambang, (2021) menunjukkan bahwa penerapan model pembelajaran kooperatif tipe snowball throwing dapat meningkatkan prestasi belajar IPS siswa kelas V di Sekolah Dasar Negeri 47 Kota Bengkulu. A \& Amran, (2017) menunjukan bahwa Hasil penelitian adalah sebagai berikut; (1) dengan menggunakan pendekatan Kooperatif Tipe Snowball Trawing pada siswa kelas V SD Mappala dapat meningkatkan hasil belajar siswa pada mata pelajaran IPS, (2) siswa sudah aktif dalam pembelajaran pendekatan Kooperatif Tipe Snowball Trawing, (3) guru mampu melaksanakan pembelajaran pendekatan Kooperatif Tipe Snowball Trawing. 


\section{Simpulan dan Saran}

Metode Snowball Throwing untuk meningkatkan motivasi dan hasil belajar siswa pada pembelajaran agama hindu. model snowball throwing memberikan suasana pembelajaran yang lebih menarik dimana siswa aktif belajar sambil bermain dengan pertanyaan yang dikemas semenarik mungkin. Metode snowball throwing menstimulus siswa untuk menyelesaikan masalah, komunikasi, penalaran, dan kepercayaan diri.

\section{Daftar Rujukan}

A, N., \& Amran, M. (2017). Penerapan Model Pembelajaran Kooperatif Tipe Snowball Throwing Untuk Meningkatkan Hasil Belajar Siswa Pada Mata Pelajaran Ips Kelas V Sdn Mapala Kota Makassar. JIKAP PGSD: Jurnal Ilmiah Ilmu Kependidikan, 1(1), 11. https://doi.org/10.26858/jkp.v1i1.5041.

Agustina, T. A. H., \& Akmal, A. (2015). Penerapan Metode Snowball Throwing Berbantuan Media Konkret Untuk Meningkatkan Keaktifan dan Hasil Belajar IPA Siswa Kelas IV Sekolah Dasar. Jurnal $\begin{array}{ccr}\text { Pendidikan Dasar PerKhasa, } & \text { 1(April). }\end{array}$ https://jurnal.stkippersada.ac.id/jurnal/index.php/JPDP/article/view/37/40.

Amirullah, A. H., \& Hardianti. (2016). Pengaruh Motivasi Belajar Terhadap Hasil Belajar Siswa Kelas X Jurusan Administrasi Perkantoran SMK YPLP PGRI 1 MAKASSAR. Jurnal Office, 2(2), 189-194.

Bambang, S. (2021). Penerapan Model Pembelajaran Kooperatif Tipe Snowball Throwing. Educate, 6(1), 9-16. https://doi.org/10.32832/educate.v6i1.4101.

Dinarto, N. A. (2019). Eam Assisted Individualization) Terhadap Hasil Belajar Siswa Pada Mata Pelajaran Ekonomi Di Sma Negeri 1 Banyuasin 1. Junal Neraca, 3(2), 215-226.

Fauziah, A., Rosnaningsih, A., \& Azhar, S. (2017). Hubungan Antara Motivasi Belajar Dengan Minat Belajar Siswa Kelas Iv Sdn Poris Gaga 05 Kota Tangerang. Jurnal JPSD (Jurnal Pendidikan Sekolah Dasar), 4(1), 47. https://doi.org/10.26555/jpsd.v4i1.a9594.

Fitriani, F., Jamal, M. A., \& Wati, M. (2013). Meningkatkan Hasil Belajar Siswa Melalui Model Generatif Learning Dengan Pendekatan Kontekstual. Berkala Ilmiah Pendidikan Fisika, 1(1), 47. https://doi.org/10.20527/bipf.v1i1.860.

Fitriani, I. N., Al-Ghozali, M. D. H., \& Ashoumi, H. (2019). Efektivitas Metode Pembelajaran Snowball Throwing Pada Mata Pelajaran Al-Qur'an Hadist Untuk Meningkatkan Minat Belajar Siswa Kelas $\mathrm{XI}$ di MAN 1 Jombang. At-Tuhfah: Jurnal Studi Keislaman, 8(2), 29-37. https://journal.unnes.ac.id/nju/index.php/JPTM/article/download/9143/5957.

Gusti, A. M. A. P. (2019). Pengaruh Metode Pembelajaran E-Learning dan Snowball Throwing Terhadap Prestasi Belajar Mahasiswa di Kelas Kalkulus Institut Teknologi dan Bisnis Stikom Bali. Square: Journal of Mathematics and Mathematics Education, 1(2), 103. https://doi.org/10.21580/square.2019.1.2.4265.

Gustomo, A., \& Sudarman. (2015). Hasil Belajar Siswa Pada Kompetensi Memperbaiki Unit Kopling Dan Komponen-Komponen Sistem Pengoperasian. Jurnal Pendidikan Teknik Mesin, 15(2), 59-63. https://journal.unnes.ac.id/nju/index.php/JPTM/article/download/9143/5957.

Januwardana, I. G. A., Zulaikha, S., \& Putra, M. (2014). Pengaruh Metode Snowball Throwing Berbantuan Media Sederhana Terhadap Hasil Belajar Matematika Siswa Kelas V Sd Gugus 1 Kuta Badung. MIMBAR PGSD Undiksha, 2(1).

Kurniawan, M. U. (2017). Perbedaan Hasil Pembelajaran Akuntansi Menggunakan Metode Snowball Throwing Dan Metode Konvensional Pada Siswa Kelas XI IPS SMAN Arjasa. Assets: Jurnal Akuntansi Dan Pendidikan, 6(1), 42. https://doi.org/10.25273/jap.v6i1.1292.

Makhfud, \& Imron, A. (2020). Efektifitas Metode Pembelajaran Snowball Throwing Pada Mata Pelajaran IPA Kelas V SDIT Al Azhar Kota Kediri. Journal of IIlamic Elementary Education, 2(September), 1122. https://ejournal.iai-tribakti.ac.id/index.php/pgmi/article/view/1335/765.

Mufid, F. (2017). Spiritual Teaching Dalam Membentuk Karakter Siswa Di Smk Islam Tsamratul Huda Tahunan Jepara. Edukasia: Jurnal Penelitian Pendidikan Islam, 11(2), 253. https://doi.org/10.21043/edukasia.v11i2.1775. 
Mulyasih, P. S., \& Suryani, N. (2016). Pengaruh Disiplin Belajar, Lingkungan Keluarga, Dan Motivasi Belajar Terhadap Prestasi Belajar Mata Pelajaran Pengantar Administrasi. Economic Education Analysis Journal, 5(2), 602-602. https://doi.org/http://journal.unnes.ac.id/sju/index.php/eea.

Nafisah, A. (2014). Arti Penting Perpustakaan Bagi Upaya Peningkatan Minat Baca Masyarakat. Jurnal Perpustakaan Libraria, https://doi.org/http://dx.doi.org/10.21043/libraria.v2i2.1248.

2(2), $\quad 70-81$.

Oktiani, I. R. P. (2017). Kreativitas Guru dalam Meningkatkan Motivasi Belajar Peserta Didik. Jurnal Kependidikan, 5(2), 216-232. https: //doi.org/10.24090/jk.v5i2.1939.

Putri Ningrat, S., Tegeh, I. M., \& Sumantri, M. (2018). Kontribusi Gaya Belajar Dan Motivasi Belajar Terhadap Hasil Belajar Bahasa Indonesia. Jurnal Ilmiah Sekolah Dasar, 2(3), 257. https://doi.org/10.23887/jisd.v2i3.16140.

Rachmah, L. L., Sunaryanto, \& Yuniastuti. (2019). Pengaruh Lingkungan Keluarga dan Fasilitas Keluarga terhadap Motivasi Belajar dan Hasil Belajar. Journal of Chemical Information and Modeling, 53(9), 1689-1699. https://doi.org/http://dx.doi.org/10.17977/jptpp.v4i9.12701.

Rosidah, A. (2017). Penerapan Model Pembelajaran Kooperatif Snowball Throwing Untuk Meningkatkan Hasil Belajar Siswa Pada Pembelajaran Ips. Jurnal Cakrawala Pendas, 3(2). https://doi.org/10.31949/jcp.v3i2.593.

Sartono, L. N. (2017). Pengaruh Metode Snow Ball Throwing Terhadap Hasil Belajar Matematika Siswa Sd. $\begin{array}{llll}\text { Elementary School Education } & \text { Journal, }\end{array}$ http://103.114.35.30/index.php/pgsd/article/viewFile/1400/1183.

Sudikno, I. S., \& Aminah, Y. S. (2014). Pengaruh Lingkungan Keluarga, Lingkungan Sekolah, Disiplin Belajar Dan Motivasi Belajar Terhadap Prestasi Belajar Ekonomi Siswa Sma Kelas Xi Ips Sma Pgri 1 Taman Pemalang. Economic Education Analysis Journal, 3(1), 46-51.

Yuliati. (2015). Efektifitas Penggunaan Model Kooperatif Tipe Snowball Throwing Untuk Meningkatkan Hasil Belajar Siswa Pada Materi Sistem Pertidaksamaan Linear Di Kelas Xi-Is-2 Sma Negeri 7 Banda Aceh. Jurnal Peluang, 3(2), 65-78. 